\title{
I. Zusammenstellung
}

\section{der im ersten Bande enthaltenen Entscheidungen nach den Seeämtern.}

I. Kaiserliches Ober-Seeamt 19 Entscheidungen, nämlich die Nummern: 38, 40, $66,80,82,83,121,122,129,141,142,145,146,159,160,161,169$, 170 und 171 .

2. Seeamt zu Königsberg ro Sprüche, nämlich die Nummern: 9, 17, 23, 57, 93, 99, 100, 170, 175 und 217.

3. Seeamt zu Danzig 8 Sprüche, nämlich die Nummern: 5, 8, 42, 75, 114, 125 , 166 und 229.

4. Seeamt zu Stettin 17 Sprüche, nämlich die Nummern: 13, 33, 54, 6o, 67, $68,69,87,92,95,123,129,137,147,183,184$ und 208.

5. Seeamt $z$ u Stralsund 37 Sprüche, nämlich die Nummern: 30, 31, 43, 44, 52, $62,70,77,82,96,97,98,103,104,105,118,119,130,135,136,146$, $160,161,178,185,186,187,188,194,195,198,199,224,225,233,234$ und 235 .

6. Seeamt zu Rostock 12 Sprüche, nämlich die Nummern: 32, 64, 65, 86, 1 II, $112,115,140,159,164,191$ und 237.

7. Seeamt zu Lübeck 2 Sprüche, nämlich die Nummern: 132 und 226.

8. Seeamt zu Flensburg 9 Sprüche, nämlich die Nummern: 25, 4I, 56, 91, 106, 153, 154, 205 und 206.

9. Seeamt zu Tönning ro Sprüche, nämlich die Nummern: 21, 34, 84, 150, 169, $174,192,203,213$ und 231.

10. Seeamt zu Hamburg 59 Sprüche, nämlich die Nummern: 2, 3, 14, 16, 19, $24,26,29,35,36,37,39,45,48,51,55,59,61,63,72,73,78,79$, 81, 102, 109, 110, 113, 117, 120, 127, 128, 133, 134, 141, 143, 144, 145, $148,152,155,157,158,165,171,173,181,193,202,204,209,210,211$, $212,214,218,219,230$ und 239.

I1. Seeamt $z u$ Bremerhaven 20 Sprüche, nämlich die Nummern: 6, 12, 27, 28, $46,47,58,71,74,76$, 101, 124, 138, 139, 172, 180, 182, 197, 200 und 216.

12. Seeamt zu Brake 19 Sprüche, nämlich die Nummern: I, 10, II, 15, 18, 50, $85,107,116,126,131,149,151,162,163,196,201,207$ und 223.

13. Seeamt zu Emden 35 Sprüche, nämlich die Nummern: 4, 7, 20, 22, 38, 49, $53,66,80,83,88,89,90,94,108,121,122,142,156,167,168,176$, 177, 179, 189, 190, 215, 220, 221, 222, 227, 228, 232, 236 und 238. 